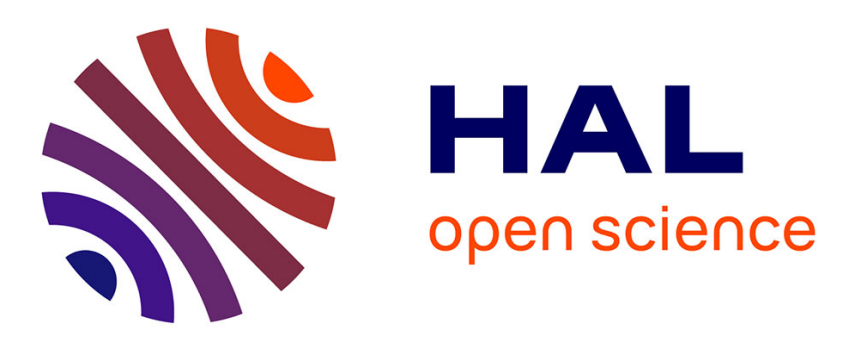

\title{
Hindu Temples and Development of Localities in Tamil Nadu (South India) \\ Pierre-Yves Trouillet
}

\section{To cite this version:}

Pierre-Yves Trouillet. Hindu Temples and Development of Localities in Tamil Nadu (South India) . Eric Denis \& Marie-Hélène Zérah. Subaltern Urbanization in India: An Introduction to the Dynamics of Ordinary Towns, Springer, pp.311 - 334, 2017. hal-01535659

\section{HAL Id: hal-01535659 \\ https://hal.science/hal-01535659}

Submitted on 20 Jan 2018

HAL is a multi-disciplinary open access archive for the deposit and dissemination of scientific research documents, whether they are published or not. The documents may come from teaching and research institutions in France or abroad, or from public or private research centers.
L'archive ouverte pluridisciplinaire HAL, est destinée au dépôt et à la diffusion de documents scientifiques de niveau recherche, publiés ou non, émanant des établissements d'enseignement et de recherche français ou étrangers, des laboratoires publics ou privés. 
To cite this book chapter: Trouillet, Pierre-Yves, 2017, «Hindu Temples and Development of Localities in Tamil Nadu (South India) ». In Subaltern Urbanization in India: An Introduction to the Dynamics of Ordinary Towns, Denis É. \& M.-H. Zérah (eds.), Delhi, Springer, "Exploring Urban Change in South Asia Series", pp. 311-334.

\title{
Hindu Temples and Development of Localities in Tamil Nadu (South India)
}

\author{
Pierre-Yves Trouillet \\ CNRS \\ Centre for South Asian Studies (CNRS-EHESS)
}

\begin{abstract}
Based on six case studies taken into the regional context of Tamil Nadu (the "Tamil country" in South India), the article demonstrates that Hindu temples take part actively to the development of their settlements in many ways, and that they locally produce some centrality which is able to trigger phenomena of local development. The case of the old temples shows that these places of worship can structure urban morphologies and that economic activities are often set up on temple lands. The study of new temples confirms these observations and sheds light on several strategies of actors associated with local development processes, such as commercial or real estate development around temples, or the purchase of lands and the creation of medical and educational establishments by the trusts managing the places of worship.
\end{abstract}

\section{Introduction}

/p.311/ Temples (koyil or kovvil in Tamil) have been places of major importance for South Indian society for more than 15 centuries. Today they are present in most settlements in Tamil Nadu, as is the case everywhere in India. They come in many sizes, ranging from small village shrines to large pilgrimage centres, and some have become very rich institutions thanks to the lands and money they have been endowed with over the centuries. According to the Hindu Religious and Charitable Endowment Department (HR\&CE ${ }^{1}$ ), which is in charge of the supervision of all the Hindu temples in Tamil Nadu, the 36,000 temples registered in the state owned over 4 lakhs ${ }^{2}$ of agricultural lands. They were rented to more than 1 lakh of tenants in 2014. Their immovable assets generated an income of more than 200 crores $^{3}$ INR between 2011 and $2014^{4}$.

In addition, temple buildings and renovations have increased manifold throughout Tamil Nadu over the last three decades ${ }^{5}$. Small and large temples are $/ \mathbf{p . 3 1 2} /$ multiplying in villages as well as in

\footnotetext{
${ }^{1}$ The HR\&CE succeeded the Hindu Religious Endowments Board formed in 1926. For a complete report on the temple policy in the Tamil country from the $19^{\text {th }}$ century to the 1980 s, see Presler (1983 and 1987).

${ }^{2}$ In th Indian numbering system, a lakh is a unit equal to one hundred thousand.

${ }^{3}$ A crore is equal to ten million.

${ }^{4}$ Tamil Development, Religious Endowments and Information Department, Hindu Religious and Charitable Endowments Department, Demand N47, Policy note 2014-2015, 2014, 165 p.

${ }^{5}$ As Chris J. Fuller (2003) noticed, the arrival of the Brahman Jayalalithaa at the post of Chief Minister of Tamil Nadu in the early 1990s encouraged the growing involvement of the regional government in ritual renovations of temples (kumpapișekam) and proves the weakening of the atheist and non-Brahman ideologies in the state.
} 
towns and metropolises, and pilgrimage sites attract increasing numbers of devotees, which leads to urban growth, a phenomenon that we also observe in many other regions in India (Das and Ray 2008 ; Shinde and Pinkney 2013). The development of guru (saint) devotion and the growth in religious activities among the urban middle class ${ }^{6}$ and " backward classes" temple sites. Another noteworthy tendency concerns the countless temples involved in charitable activities and local development projects. Indeed, thanks to their regular incomes and the legislation of religion in India (especially in Tamil Nadu), Hindu temples are allowed to develop such activities on the lands with which they have been endowed.

All these current trends and observations lead us to ponder the relationships that exist between Hindu temples and the development ${ }^{8}$ of settlements in Tamil Nadu. Astonishingly, this issue has received little attention in urban and development studies in India, although there are a few notable exceptions (Reiniche 1985; Guilmoto et al. 1990; Gaucher 2007; Shinde and Pinkney 2013; Narayanan 2015). Indeed, although there is extensive literature on urban dynamics as well as on Hindu "traditions", gurus, temples and pilgrimages in India, there is a gap when it comes to works dealing with the connections between temples and the development of localities, especially in recent times.

Based on a study of several old and new temples, this contribution examines how these religious institutions are central to triggering local development and settlement growth, and shows to what extent these religious institutions contribute to a form of in situ urbanisation. As Denis et al. (2012: 56) argue, urbanisation in India is also characterised by an "autonomous growth of settlements generated by market and historical forces which are not 'dependent' on large metropolises [...] or "planned' cities". Following this observation, this contribution aims to show that temples are involved in such phenomena of "subaltern urbanisation" (ibid.), first by identifying different situations where a Hindu temple produces a centrality and accompanies the development of its locality and second by presenting the diversity of relationships that exist between temples and the growth of settlements in Tamil Nadu.

More broadly, another objective of this contribution is to highlight the role the "spatial prohibition of ownership" (Desmarais 2001) associated with sacred places plays in the emergence and structuration of localities. Indeed, structural geography $/ \mathbf{p . 3 1 3 /}$ considers that human settlements emerge from such spatial prohibition of owner- ship, which mediates the transformations of the natural environment into culturally invested spaces (ibid.). In addition, this chapter provides an illustration of the interest of the "economics of religion" (Iannacone 1998; Obadia 2013) in addressing the role played by Hindu temples in their settlements, for it becomes apparent that these religious institutions are not only symbolic landmarks but also real actors in local economies.

In this perspective, fieldwork was conducted in two sets of localities (Fig. 1) in June/July 2012 and in April 2013. The first three sites studied were towns of less than 100,000 inhabitants, where the Government of Tamil Nadu (HR\&CE) directly manages old temples. The three other localities studied are much smaller $/ \mathbf{p . 3 1 4} /$ settlements of less than 5000 inhabitants, where private individuals have founded recent temples. The first set of localities enables us to evaluate to what extent old temples managed by the Government participate in the growth and the economy of their town, whereas the second allows us to identify some emerging processes through which new temples stimulate local

\footnotetext{
${ }^{6}$ Because of increasing incomes and time available for leisure, the Indian middle class is becoming a significant target for religious tourism and other "businesses of devotion" (Shinde and Pinkney 2013; Obadia 2013). Besides, Punzo-Waghorne (2004) demonstrated that white-collar profes- sionals who solicited donations from a similar class of people sponsored most of the mushrooming temples in the suburbs of Chennai.

${ }^{7}$ Official terminology to classify castes which are socially and educationally disadvantaged.

${ }^{8}$ The term "development" is understood here only in its most basic sense, which refers more to the spatial, economic and demographic growth of localities than to their human or sustainable development, although many trusts affiliated to Hindu temples in India are involved in charitable activities (hospitals, educational institutions, etc.).
} 
developments and economies. Before describing these fieldworks and phenomena in detail, we present the historical importance of Tamil temples in local development and their current administrative patterns.

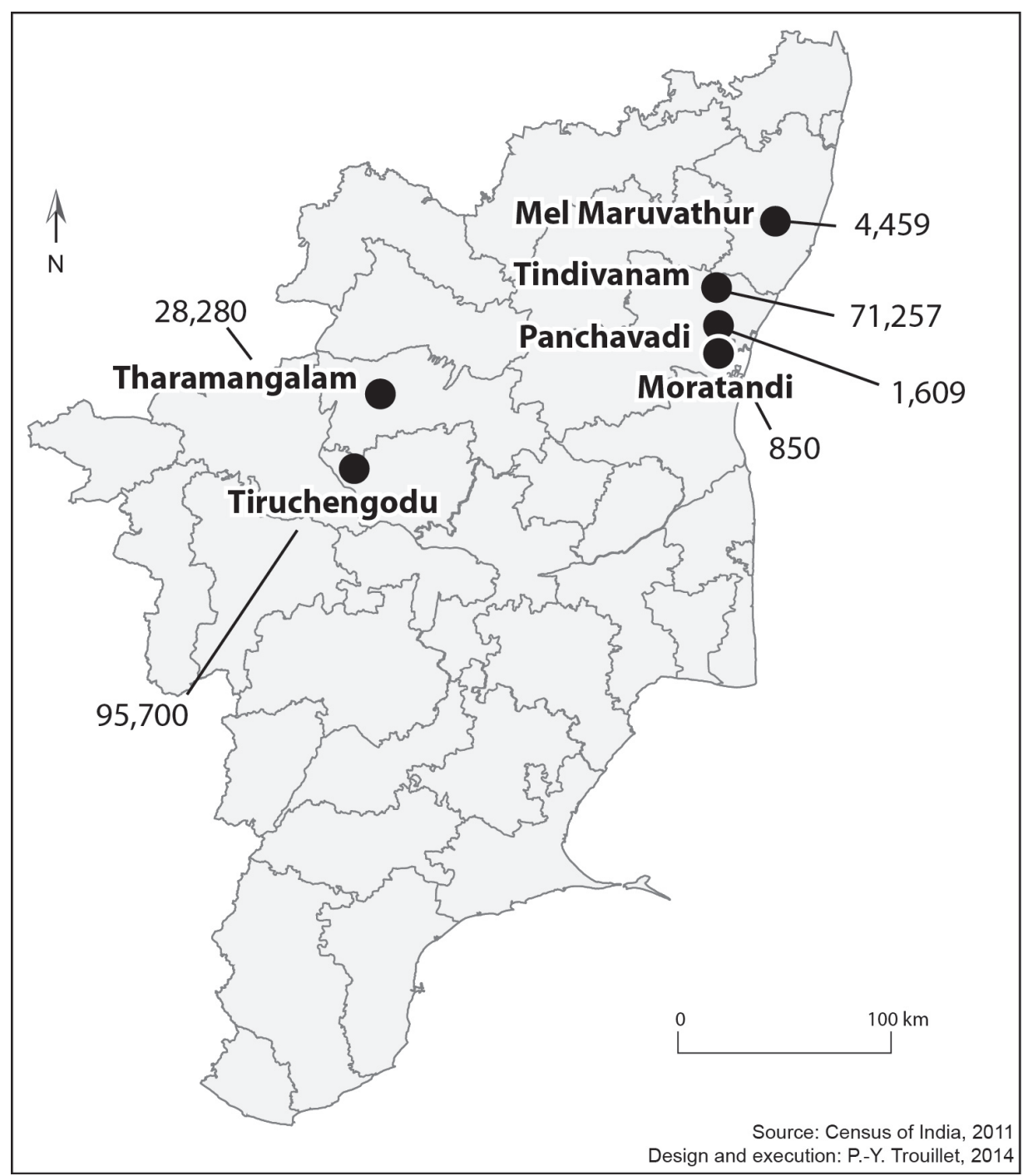

Fig. 1 Locations of fieldworks in Tamil Nadu and their census population in 2011

\section{The Historical Importance of Temples in Tamil Nadu and Their Contemporary Administration}

The involvement of temples in the development of settlements in south India is not a new phenomenon. Nevertheless, contemporary situations reveal several differ- ences from the ancient contexts, especially because of the new modes of admin- istration of religious institutions introduced by the British. This section provides insights into the historical linkages between temples and local development in the Tamil country; it then presents the current administrative systems governing tem- ples, which dictate the temples' capacity to take part to the growth of their locality. 


\subsection{The Historical Linkages Between Temples and Local Development}

Historians of the region have profusely commented upon the economic importance of Hindu temples in medieval south India. Without exception, the temple is seen as a central place in the agrarian economy of south India, before the extension of British control in the eighteenth and nineteenth centuries. Historians emphasised the variegated economic functions of many medieval temples, which were landholders, employers, banks and consumers of goods and services (Nilakanta Sastri 1937; Stein 1960, 1961; Karashima 1984; Dayalan 1992). Most importantly, temples were strongly connected with the expansion of south Indian urbanism and the development of irrigation.

Since the Pallava dynasty (sixth to ninth centuries AD), temples have developed a growing influence over the rising political and commercial networks in south India. During the following reigns of the Chola kings (ninth to thirteenth centuries), who succeeded in uniting the whole of the Tamil country under their rule, many areas of the region experienced the growth of small towns around temples. This process complies to a large extent with the definition of subaltern urbanisation because, according to James Heitzman, the urban development of these places around temples during this period "were relatively independent, indigenous /p.315/ developments that were quite new in south India", and whose developmental pat- terns "were subject to few external influences" (Heitzman 1987: 818).

The process often started with the endowment and establishment of a Brahmin settlement (brāhmadēya) whose resources shifted slowly into the hands of deities of important temples. Religious endowments were made by kings, secular donors and Brahmins to provide income for the temple maintenance and the performance of festivals honouring the deities. These endowments were generally of two kinds: lands and money. Land endowments included plots of cultivated land, portions of villages or entire villages, and became the main resources of temples. These temple lands (dêvadāna) could be located inside or outside the temple village and this could create extended networks of temple landholdings in a large number of vil- lages. Of course, the development of local temples interacted with the expansion of commercial networks centred on the mercantile communities.

Small settlements of Brahmins, merchants and artisans gathered near holy places and enjoyed important capital inputs from the donations received by the temples, and employment within the temple ritual and administrative complexes incited larger numbers of people to gather around temples. Although it remained con- centrated in the streets surrounding the temple enclosure, the expansion of the residential areas followed the patterns of prior settlements with their spatial segregation into distinct neighbourhoods based on caste and/or occupational identities. Nevertheless, as James Heitzman noted, "the "urban" character of these adminis- trative units rested on the integration of a number of individual settlements, grouped around ritual centres, which preserved in themselves the characteristics of the vil- lage" (ibid.). Besides, the centrality of the temple sites and their interactions with their broader hinterland occurred at religious as well as economic and political levels.

Temples were also among the most important agencies for agricultural devel- opment during the Chola and Vijayanagar periods (900-1610 AD), especially in what concerns irrigation (Stein 1960, 1961; Heitzman 1987). Indeed, neither the Chola nor Vijayanagar empires had a department of irrigation nor public works to deal with agricultural improvements, and irrigation programmes were frequently carried out by temples. Alongside irrigation programmes, temples were also important centres providing capital inputs for the agrarian development of their area. The money belonging to 
the temple was frequently loaned to village assem- blies for developmental purposes, but also to commercial firms and individuals.

\subsection{Temple Administration and Taxation}

During the pre-colonial period, temples and political authorities were mutually supportive. Kings looked after temples by offering lands and money, whereas the religious institutions supported and consecrated the legitimacy and authority of the kings during rituals through symbolic considerations (Appadurai 1981; Appadurai and Breckenridge 1976; Reiniche 1985).

/p.316/ The modern state changed the situation as far as its legitimacy was no longer based on the temple, nor was it dependent on these institutions (Presler 1983, 1987). From the colonial period onwards, successive governments became involved in the control and the management of temples and the regulation of the use of their resources. The aim was to avoid wastage and misappropriation of "public goods" that the resources of the temple represented, as well as problems of mismanagement and corruption (ibid.; Tarabout 2006). To this effect, after different legislations were implemented, with the Madras Regulation VII of 1817, the state instituted itself as the new protector of most of the main temples of the Tamil country, which are defined as "public trusts".

Today, the legal framework of the public practice of religion in India is defined by the Constitution ${ }^{9}$. Article 26 guarantees the right to establish and maintain religious and charitable institutions, but also to own and administer movable and immovable properties dedicated to this purpose. Yet there is no uniform legislation concerning the practice of religion in public, valid all over India and for all Indians. As Clémentin-Ojha (2010: 345, my translation) noted, "the Indian Constitution entrusts the states of the Union to exert their responsibilities over the administration and control of pious institutions, and to legislate according to their own historical traditions". Nevertheless, the public legislation applicable to Hindu temples is governed by a double set of laws, a combination of Hindu and British legislation. The legal personality of a temple deity exists once there is a regular worship addressed locally and the necessity to manage some assets in order to perpetuate the worship (Annoussamy 2001: 299). For this purpose, the founder has to register the deed of donation of properties to the temple deity and the trust that is to be in charge of the temple. Indeed, all the resources of any Hindu temple belong to its tutelary deity (more precisely to its local "image") and are inalienable (Varadachari 1968; Presler 1983, 1987; Reiniche 1989; Mukherjea 2003; Clémentin-Ojha 2010). The deity is legally represented by its custodian(s), called "trustee(s)", who can be either the founder of the shrine and the trust, the person(s) designated by him or by the administration to assume this function or the successor(s) of this person. Trustees have extensive powers as they carry out the worship of the temple deity and administer its assets (money, jewellery, lands, movable properties, etc.), which can

be considerable.

Hindu temple trusts can be public or private. This distinction is an important one as it determines their taxation obligations. A public religious trust is a dedication of property for the use or benefit of the public at large, whereas a private religious trust is the dedication of the property for the worship of a family (or community) god in which the public is not interested. The public or private status of the trust in charge of a temple depends on the purposes and on the beneficiaries of the trust defined by its founder when he registers the trust deed (which cannot be changed after reg- istration). This

\footnotetext{
${ }^{9}$ For a complete overview of the connections between religion and justice in India and Nepal, see Berti et al. (2016).
} 
point is crucial as the Income Tax Act of 1961 exempts public /p.317/ religious trusts (and charitable trusts) from taxation but not private ones. This implies that, to be exempted, a religious/temple trust must be open to the public or recognised as a public-interest organisation (it is then considered a "charitable trust"). It is worth noting that one or several charitable trusts (exempted from taxation) can be affiliated to a private religious trust, which permits strategies for investments and local development. Indeed, the tax exemption of public religious institutions is an important issue for local economic development because, as we show, temple founders and trustees can acquire movable and immovable assets (including lands, buildings or colleges) through religious and charitable trusts. Nevertheless, public religious trusts and charitable trusts must neutralise their benefits to enjoy the exemption from taxes. They can save a maximum of $25 \%$ of their annual income, but to benefit from tax exemption they must spend $85 \%$ of their total annual income for the purposes of the trust.

As soon as a temple is open to the public and/or receives money offerings from devotees (in hundi-s) and collects an income of over 10,000 INR per year, it falls under the supervision of the HR\&CE ${ }^{10}$, whose inspectors audit the temple accounts yearly. As long as there is no report of mismanagement, internal conflict or tax fraud, the initial trust can continue to manage the temple and to appoint its trustees. Otherwise, the HR\&CE takes control of the temple and appoints a fit person $($ takkār $)$, an Executive Officer and a new board of trustees ${ }^{11}$.

The public temples directly administered by the HR\&CE (which include those generating the largest incomes, such as Palani, Madurai, Tiruchendur, Srirangam and Rameshwaram ${ }^{12}$ ) are managed by a board called "Devasthanam" (têvastānam, "the place of the god"), consisting of a staff of civil servants and a board of trustees. The term Devasthanam refers to the temple as well as the board. The board of trustees of public temples, which is appointed for a period of 2 years, can be composed of "hereditary" or "non-hereditary" trustees. Hereditary trustees are involved in the management of former private temples that have been declared public but in which a particular community still has honorary rights; they are hence chosen from this community. The nonhereditary trustees are appointed to each temple by the HR\&CE. Each board of trustees should consist of no less than three persons and no more than five. Boards of non-hereditary trustees should consist of members, one of whom is from a Scheduled Caste or Scheduled Tribe, and one of whom is a woman. Besides, as Franklin Presler noted: "The board of trustees, especially its managing trustee, is the temple's top legal authority. Trustees stand high in the order of precedence in temple rituals, temple honours and other such regards. They can influence who gets land leases, how much rent is paid and which contractors get the lucrative building and renovation contracts [...]. The choice of /p.318/ trustee is thus at the heart of a temple's politics" (Presler 1983: 237). It is also noteworthy that, after a change of government, all temple trustees in Tamil Nadu are generally discharged, and new ones, who support the party in power, are appointed.

Nevertheless, the HR\&CE is the real commanding presence in the main temples in Tamil Nadu. Furthermore, the Department controls the activities of the trustees and the budget of all the registered temples in the state. Many HR\&CE civil servants, from the Commissioners in Chennai and at the districts headquarters to the subordinate officers, inspectors, auditors and clerks in the localities, monitor the temple's activities. Executive Officers have a strong power of authority and are key decision makers in most important public temples in which they hold office. They look after the accounts, frame the budget, supervise the staff (including priests) and organise the festivals

\footnotetext{
${ }^{10}$ Hindu Religious and Charitable Endowments Act, 1959 (Sect. 4).

${ }^{11}$ Interview with an Assistant Commissioner (Legal) at the HR\&CE Office, Chennai, April 2013.

${ }^{12}$ In 2014, the HR\&CE controlled the 320 temples that had an annual income of 10 lakhs INR and above in Tamil Nadu. Palani temple, which is the richest and busiest of Tamil Nadu, generated more than 9 crores INR of income in 2012 according to the HR\&CE.
} 
(ibid.).

\section{Old Public Temples and Their Localities}

A first kind of relationship between temples and local development concerns the temples directly administered by the HR\&CE, which means that they are open to the public and that their trustees and Executive Officers are appointed by this department. This type of temple encompasses most of the "old" Tamil temples (built during the colonial and precolonial periods), including the busiest, largest and richest ones. It refers to the temples studied in the small towns of Tiruchengodu ${ }^{13}$, Tharamangalam and Tindivanam.

Tindivanam is a municipality, populated by 71,257 inhabitants in 2011, where several old temples managed by the HR\&CE have a subregional audience. Tiruchengodu is another municipality with a population of 95,700 inhabitants in 2011, and which is renowned all over Tamil Nadu for its two large Siva temples, also controlled by the government. Tharamangalam is a panchayat town of 28,280 inhabitants (in 2011), famous for its Śiva temple and, to a lesser extent, for its power loom industry. These three localities serve as examples for us to consider the different ways in which old, public temples participate in the development of Tamil towns.

The temples in Tiruchengodu and Tharamangalam (as well as many other cities, such as Madurai or Tiruvannamalai) illustrate the "temple city" archetype (Geddes 1919), which is quite well known and represents a good example of how a temple can impact the growth of a town and its morphological structure. In these localities the temple is at the centre of the town's identity, morphology and activity. However, similar to Guilmoto et al. (1990), I only acknowledge the morphological pertinence of the "temple city" concept, as the temples of such towns rarely /p.319/ structure their whole socio-economic orientation today. Furthermore, temples administered by the HR\&CE have other ways of taking part in the economy of their locality.

\subsection{The Temple and the Origin of the Town}

The main shrine of "temple towns" often provides the locality with its singularity and gives it a symbolic importance making it attractive to devotees and activities, hence creating a certain centrality. Furthermore, in such cases, the temple is often associated with the founding myth of the locality. The shrine can thus be mythically at the origin of the town and its "proto-historic centre" (ibid.: 15). Indeed, no south Indian town has been founded at random (at least a posteriori), but always where a myth recounts that the divine manifested itself there (generally a buried statue of a linga or a goddess). In other words, "the manifestation of the divine determined the foundation of a locality" (Reiniche 1985: 76, my translation). Hence, the temple erection and worship predate the settlement, in principle or in a local story, in accordance with the theory of structural geography mentioned in the introduction. For instance, the temple of Tharamalangalam has mythically "built" its town because the place was a jungle area before its construction. According to the sthala purāna (the "story of the place") of the temple, a local king named Keti Mudali, who was living nearby, decided to establish a temple at the site of the Sivalinga he found in the forest. Then Keti Mudali, his son and grandson succeeded each other to complete the temple. Today the devotees can experience this founding myth thanks to three Vināyaka (Ganeśa) statutes which are supposed to have been installed by each of these kings at the entrance to the temple. The fact that the temple is

\footnotetext{
${ }^{13}$ For more information about Tiruchengodu, see Raman and Tastevin's contributions in this volume.
} 
at the origin of the settlement is also symbolised by the name of the town itself. Indeed, Tharamangalam is considered the place (dharā) where Śiva married Pārvatī, the spouse (maingalā) form of the Goddess.

Many other examples attest to the importance of local myths and temples for the identity and reputation of their settlements in Tamil Nadu. It is particularly the case of Madurai, which is probably the most famous temple city of the region, or Tiruvannamalai, which is supposed to have been created around a fire linga rep- resented by the inselberg overlooking the city and by the śaivite sanctuary, which leans against it. In such cases, also observable in Palani for instance, the temple consecrates a natural landmark and vice versa.

\subsection{Urban Morphology of the "Temple City"}

Similar to Madurai and Tiruvannamalai, the small towns of Tharamangalam and Tiruchengodu can be regarded as "temple cities" as their urban morphology is clearly structured around the main temple. This is not the case with Tindivanam /p.320/ where no specific temple gained sufficient importance to influence the morphology of the whole town but, here, several temples produce multiple religious centralities and sub-town morphologies in their surroundings.

The temple city archetype constitutes a good example of how a temple influ- ences the growth of a town, and in particular its urban form. Indeed, as Guilmoto, Pichard and Reiniche pointed out, in such towns (Fig. 2), the temple is "the guiding principle of the urban morphology". It "dictated the framework of past circulations and settlements by structuring the urban space until recently", it "is the fulcrum of the morphology of the whole town", and it is the "point of convergence of all the communication routes" (Guilmoto et al. 1990: 15-25, my translation).

In temple towns the main temple is located at the principal crossroads of the locality, it defines the centre and determines the best location for retail trade because it attracts many visitors. In Tharamangalam and Tiruchengodu, the biggest con- centration of retail shops and trading activities are clustered in the main streets surrounding the temple. Logically, a number of these shops sell religious goods, especially near the entrance to the temple, but many other shops trade in different kinds of products. This variety of goods sold near the temple is highly significant of the central importance of the main shrine for the locality.

The structuring influence of the temple also involves spatial restrictions based on socio-religious norms. Many trading activities are restricted near the temple: the sale of meat, alcohol or tobacco, because of the impure (aśaiva) nature (guna) of such products is incompatible with the holy nature

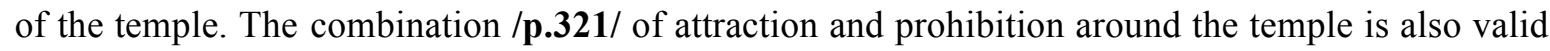
with regard to resi- dence. For centuries, the "lowest" castes (Scheduled Castes) have been forbidden to live near the main temples, whereas the "upper" castes used to reside close to it. In "traditional" Tamil localities, Brahmins used to settle near the main temple in a mono-caste neighbourhood called "agrahäram". In Thiruchengodu, the southern street adjacent to the main temple is also called "Gurrukkal street", which means the street where the Brahmin priests live. Such observations are not new but deserve attention as they concern the role of the temple in the segmentation of residence and activities, and thus in the design of urban morphology. 


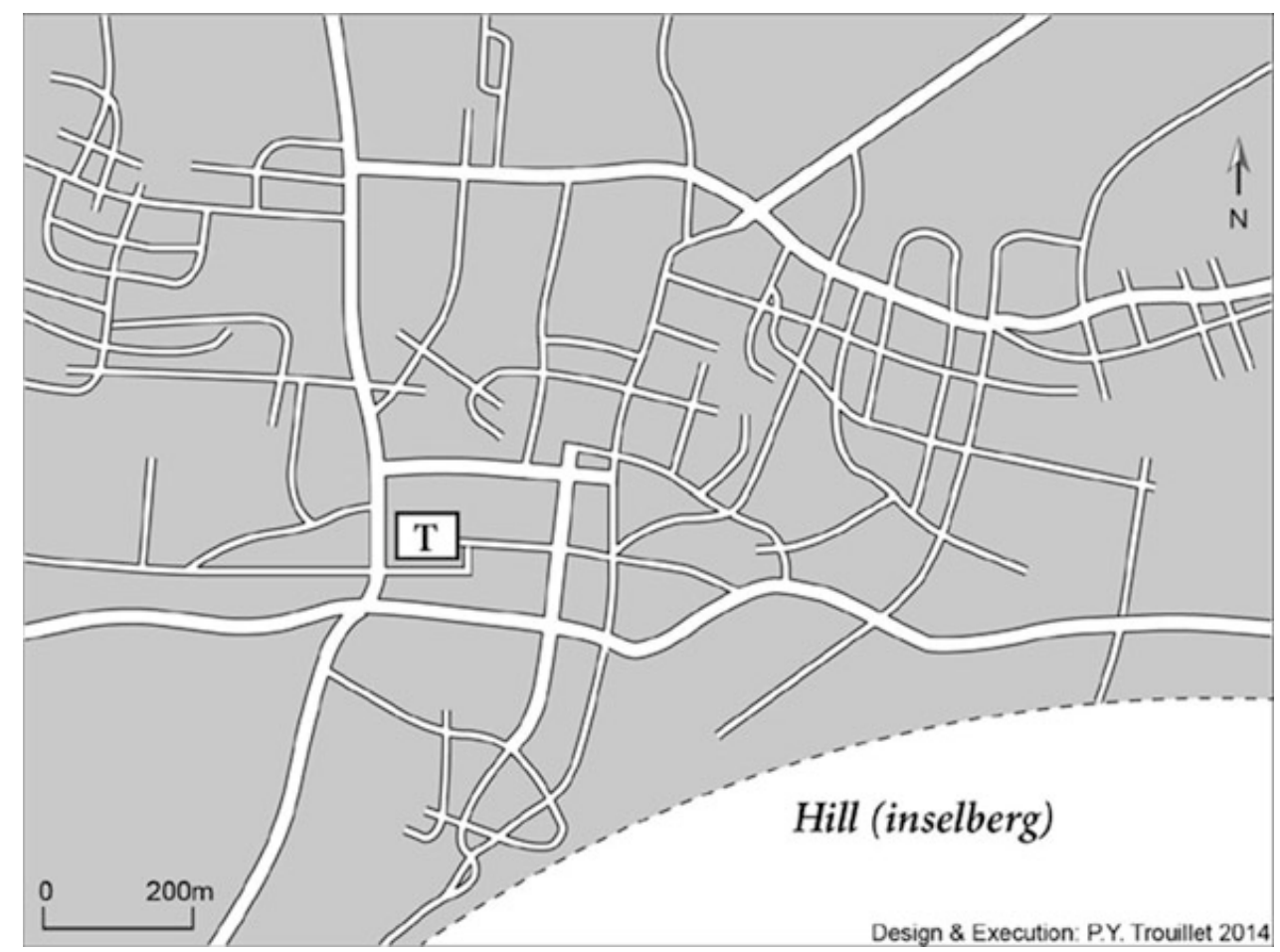

Fig. 2 The central location of the main temple of Tiruchengodu and its influence on the urban morphology (the other large Siva temple of Tiruchengodu is situated on the top of the southern hill)

\subsection{Activities on Public Temple Lands}

What is also highly noteworthy is that some lands on which shops are implanted belong to temples (Devasthanams). This is not only the case of temple towns because most Devasthanams own lands in Tamil Nadu. In such cases, the economic role of the temple is more obvious as far as economic activities take place on its landed properties. It is notably the case in Tharamangalam, where the 44 shops located on the 4 streets surrounding the temple belong to the Devasthanam. These shops sell different kinds of products such as religious goods, fabric, jewellery, household goods, food and so on. Of course, no aśaiva (non-vegetarian) restaurant is allowed on temple lands in Tamil Nadu because of the socio-ritual norms mentioned above. In the case of Tharamangalam, the Devasthanam owns the land and the shop buildings, and rents them out for a period of 1-3 years. As in all the public temples controlled by the HR\&CE, the lease amount is defined by auctions. Devasthanams possess agricultural lands as well, in the locality and outside of it; these are rented by lease and auctions, the frequency of which depends on the type of property (buildings, dry or wet lands etc.). (I mentioned earlier that the HR\&CE temples control more than 4 lakhs of acres of land). This land can be cultivated, unoccupied or occupied by private houses whose owners enjoy a low rent in com- parison with market prices. Devasthanams always retain possession of the title deeds of the land (patt $\bar{a}$ ) although houses can be sold on the black market between private individuals. It is also worth noting that, as in former times, the lands owned by Devasthanams can be situated far from the settlement where the temple is located as these lands have been donated by a great variety of donors. For that matter, as is the case in some other states, the Tamil Nadu 
government recently launched a program to collect data on lands belonging to public temples to identify the temple lands that have been lost over the years and often encroached. Officially, "encroachments of temple lands, to the extent of 1,564.75 acres of land, 286,1004 grounds of sites and 76,2375 grounds of buildings, were cleared and returned to the possession of temples" ${ }^{14}$ by the previous Jayalalithaa Government (May 2011-September 2014). /p.322/ The total value of these assets is approximately $1,687.44$ crore INR $^{15}$. Furthermore, subject to certain conditions, steps were taken to regularise the persons who have encroached upon temple lands in groups and have been living there for more than 30 years as tenants ${ }^{16}$.

To sum up, temples participate in the identity and reputation of their locality even beyond the urban limits, and many of them take part in the structuration of urban morphologies and economies. Furthermore, Hindu temples own land resources on which economic activities are implanted, and these can be located in or outside the temple locality. Thus their role is not only symbolic because they also contribute to structuring urban form by enabling the development of economic activities, by influencing land use through spatial restrictions, and by expanding their zone of influ- ence through rural-urban linkages. As such, they are actors per se. The following cases share most of these features, yet they have other effects on the growth of their locality, especially because they are much newer and are managed by private individuals.

\section{Melmaruvathur: Guru Temple Trusts and Local Development}

The case of Melmaruvathur is quite different because it has recently been constituted in a much smaller settlement than the towns mentioned previously, and because its main temple has given rise to two very rich religious and charitable trusts associated with it. Moreover, its founder is the spiritual leader of the place. Indeed, the Ādi Parāśakti Temple of Melmaruvathur, which has gathered increasing crowds of devotees since its creation in 1977, was founded by its living guru Bangaru Adigalar, better known by the name "Ammā" ("Mother" in Tamil). This case is particularly interesting because the temple and its connected trusts are undoubtedly the main factors and actors of the development of the locality. It also provides a good illustration of the contemporary creation of religious sites in unknown localities, which progressively succeed in being included in the venerable network of famous Hindu pilgrimage centres.

\subsection{The Place and the Guru}

In 2011, the locality of the Ādi Parāśakti Temple was inhabited by 4459 people living in two adjacent panchayat villages: Melmaruvathur itself (1748 inhabitants) /p.323/ and Sothupakkam (2711 inhabitants). Astonishingly, in this small place one can find a police station, 2 bus stands, a railway station, a 1000-bed hospital, 11 high schools and colleges, a lot of accommodation and many others amenities. Why is this so? Partly because it is situated on National Highway 45, between Chennai and Trichy (92 km from Chennai), but above all because of its Ādi Parāśakti Temple and its living guru.

\footnotetext{
14 Tamil Development, Religious Endowments and Information Department (2014/2015), p. 32.

15 Ibib.

${ }^{16}$ The land must have been utilised for more than 30 years for residential purpose only. ii. The fair rent fixed as per relevant Government Order should be agreed. iii. The fair rent has to be given effect from 01/07/1998. iv. The rent due must be remitted in equal instalments in a period of 12 months and 10 months rent has to be paid as donation (ibid.).
} 
Following its construction, the number of visitors to the temple has increased manyfold and nowadays when driving along the $\mathrm{NH} 45$ it is commonplace to see numerous groups of pilgrims and devotees dressed in red, walking along the highway towards the temple. The kind of Hinduism practiced in this temple can be associated with the bhakti (devotional) and "reformed" movement: the shrine and its guru do not claim any link with Vedic rituals, the priests are not Brahmins, everyone can enter and worship in the temple and they can touch the temple deity ( $m \bar{u} r t i)$, which is not permitted in orthoprax Hinduism. As such, the temple is very popular among "backward" and "most-backward classes" (B.C. and M.B.C.).

The guru himself is not a Brahmin but a Telugu Naidu who does not wear the sacred thread (pünul) of the "high" castes. Bangaru Adigalar was born in 1941 in the very village of Melmaruvathur. According to the legend, he was attracted to meditation and religion during his childhood, and in 1966, beneath a tree, he "discovered" a svayambh $\bar{u}$, a "self-created" stone form of the Goddess $(\bar{D} \bar{e} \bar{\imath})$. He is now considered an avatār of Śakti, the Hindu divine feminine power, and can be regularly seen and worshipped by devotees during a daily darśan .

\subsection{Temple Trusts and Local Amenities}

The main sanctum sanctorum and the mandapam of the temple were installed in 1977 on Bangaru Adigalar's initiative. The following year he created the Adhiparasakthi Charitable, Medical, Educational and Charitable Trust (ACMEC), of which he is president. In 1988 he founded another trust, the Adhiparasakthi Siddhar Peetam Women's Charitable Trust (ASPWC). The reputation of the guru and the temple grew quickly and devotees rapidly began making large donations to the trusts; the funds were used to establish many amenities and institutions in the village (and elsewhere).

The first two educational institutions started by the ACMEC Trust were a Polytechnic College and a College of Pharmacy, founded in 1983. An Engineering College was established in 1984 and a Matriculation Higher Secondary School in 1985. The following year, the ACMEC Trust opened its hospital, which started out as a 300-bed facility, which is now able to handle 1000 inpatients and 1200 outpatients.

The Melmaruvathur railway station was also set up in 1986, and the first police station of the village 2 years later. A College of Physiotherapy opened in 1994, a Dental College and an Annai Illam for handicapped children in 2005, a High /p.324/ School and an Institute of Medical Sciences and Research in 2007 and a GB Public School in 2009.

All these institutions have been established in the village thanks to Bangaru Adigalar and his temple. The educational and medical institutions have been created directly under his authority through the charitable trust he founded, whereas the Tamil Nadu government implemented the transport infrastructure (railway station, bus stands and highway) and the police station, which recognised the importance and the potential of the locality since the 1980s. This shows the location's strong capacity for attraction and polarisation.

\subsection{The "Real" Population of Melmaruvathur}

Although the 2011 Census only mentions a population of 4459 inhabitants, the "real" population present everyday in Melmaruvathur is much higher. Indeed, the activities organised by the temple and its trusts regularly attract other populations that remain invisible in the Census data. Among 
them, there are approximately 3000 college students and 55 hospital doctors and their families who reside in Melmaruvathur. Between 50 and 250 volunteers are present daily to support the trust's religious and charitable activities. In addition, 2000-75,000 free meals are offered (annatānam) by the temple every day, and this represents a useful indicator to estimate the number of devotees who come to Melmaruvathur at important moments of the religious calendar (of course, the highest number of meals corre- sponds to the main festivals). Finally, the 1200 outpatients who visit the hospital daily must also be included in the estimation of the population regularly present in the locality.

In addition, even if some of this population comes from the surrounding villages, and although the easy accessibility of the place allows many devotees to return home on the day of their visit, many lodges are available for their accommodation and the ACMEC Trust recently constructed a great marriage hall.

\subsection{Extended Landholdings and Worldwide Connections}

Similar to many other temple trusts, the ACMEC trust owns landed properties outside of the locality where the temple is situated. It thus participates in the development of other places. The ACMEC trust has some lands in the panchayat town of Kalavai (Vellore district), where its first 72 acres were donated by the very influential Śankarācārya of Kanchipuram who owns a monastery (matam) there. As in Melmaruvathur, the ACMEC trust has also established colleges there. A College /p.325/ of Arts and Science, the foundation stone of which was laid by former Prime Minister Rajiv Gandhi, was opened in 1988. In 1999 the trust also established the first self-financing Agricultural College in Tamil Nadu in this town. A College of Engineering was founded by the ASPWC Trust in 2001, a Teachers Training Institute was created in 2004 by the ACMEC Trust followed by a College of Education in 2005.

In addition, the temple and its trusts receive devotees and donations from all over Tamil Nadu, as well as from other sites in India and in the United States, Canada, the United Kingdom, France, Singapore, Australia and Dubai. The trust also claims to manage over 5000 branches (called "mandrams") in different part of the world and the guru often travels within the country and overseas for spiritual tours. This shows that, thanks to the temple, the locality of Melmaruvathur is connected to other places not only in the country but also in the diaspora (hence to globalisation) independent of any metropolis.

In sum, although the accessibility of the village from Chennai and other towns should not be underestimated, this guru temple and its trusts are clearly at the origin of the emergence of a centrality. The development of this locality is thus a perfect example of how temples and temple trusts can trigger local development, especially here, as a religious, educational and medical hub.

It is worth noting that such an emergence of a centrality in a very small locality, provoked by the presence of a living guru who encouraged the foundation of temples, trusts, schools, colleges and hospitals, is in no way an exception, because it occurs in other places in India. Another good example can be observed, for instance, in the Kokamthan village (Ahmednagar district, Maharashtra), where the Vishwatmak Jangli Maharaj Ashram Trust has established and runs 10 schools, a hospital, a Doctorate of Education College, a Center for Wrestling Education and a School of Music. These activities are not limited to private temple trusts. For example, the temple of Palani, which is administrated by the HR\&CE and is the richest shrine of Tamil Nadu, runs four colleges, three schools, two schools for priests, a hospital and a children's mercy home. Finally, regarding the shrines of deceased gurus, Shinde and Pinkney (2013) recently reminded us that the 
town of Shirdi (Maharashtra), where the saint Sai Baba (ca.1832-1918) lived, was trans- formed from a humble village into a pan-Indian, even global, pilgrimage centre in less than a century.

\section{New Temple Trusts: Landmarks, RealEstate and New Local Geographies}

The two following cases concern the creation of new temples in even smaller settlements. Both temples share the same religious ideology of claiming to host the "world's highest statue" of a Hindu god: Hanumān for the first temple, Śani (Saturn) /p.326/ for the second. Of course, this is not always true ${ }^{17}$, but these assertions show that the aim of the temple founders was to make the place as attractive as possible through the transfiguration of the local landscape.

More broadly, these two last cases illustrate the capacity of new temples to create a landmark and thus to attract economic activities in their surroundings (especially in what concerns retail trade and real estate) and to reformulate local geographies. They also show how a temple trust can be a tool to buy lands and increase the land value. In addition, these last cases allow us to examine the motivations of some current temple founders.

\subsection{Evergetism at the Private Hanumān Temple}

The Paňcamukha Āñjanēya Svāmi (Hanumān) temple was consecrated in 2007 at Panchavadi, which is a settlement of 1609 inhabitants (2011), included in the Rawthankuppam panchayat village and situated $12 \mathrm{~km}$ from Puducherry, very close to National Highway 45, which makes it easily accessible. Its gigantic Āñjanēya statue, which stands 36 feet tall and 15 feet wide ("not seen anywhere else on this Earth" according to the temple website), is very striking in the village landscape. The reputation of the temple and the number of visitors increase year after year. It attracts an ever-increasing number of devotees and embodies the growing popularity of Hanumān worship in India. Indeed, major old temples dedicated to Hanumān are very rare in south India, but worship of this deity has expanded in size and popularity all over India with many temples vying to produce the largest statue (Lutgendorf 1994).

The Panchavadi temple has a very significant feature similar to another famous Hanumān temple located in Chennai (Nanganallur), both establishments being private and having the same founder. In fact, according to the regional press, it was

S. Ramani Anna, the founder-trustee of the Nanganallur temple, who "got the inspiration when he visited Pondicherry along with Veeravalli S. Santhanam, a philanthropist [cofounder of the Sattva Group, a successful company]. On passing through Panchavadi, it struck them that the temple should be built there. The latter agreed to give a portion of the land he had bought for starting an industry [...]. Dr. M. Palaniappan [the Managing Director] of Nagappa Motors has agreed to meet the cost of the Vināyaka shrine [of the sanctuary] ${ }^{, 18}$. The estimate for the entire project was 2 crores $\mathrm{INR}^{19}$.

Thus, the founder of the temple and the main donors are not residents of the locality and play complementary roles: Ramani Anna, who is well-known for his involvement and devotion to Hanumān worship in Tamil Nadu, personifies the /p.327/ religious and spiritual figure, whereas the

\footnotetext{
${ }^{17}$ For instance, one can find higher Hanumān statues in Delhi or Andhra (Lutgendorf 1994).

${ }^{18} \mathrm{Ibib}$.

19 "Hanuman's special avatar as Annihilator", The Hindu, Friday, March 07, 2003.
} 
Sattva Group and Nagappa Motors are companies that embody the economic and "kingly" entities, in reference to the duty of the past Tamil kings.

The Sattva Company settled in Panchavadi in 1999 and donated the first 1.5 acres of land for the temple, then another 13 acres to reach the current area. The Sattva Group originally specialised in transportation and logistics. Its head office is located in Chennai, but it has many other business units around Chennai and Puducherry. The Company decided to buy lands in Panchavadi in order to set up warehouses and rent containers thanks to the proximity of the site to Puducherry and its good accessibility from Chennai. In the media, the Group displays a religious and philanthropic image, especially in what concerns its founding member, Veeravalli S. Santhanam, who is depicted as a pious Vaishnavite. This explains the involvement of the Sattva Group in the construction of a Hanumān temple in this very locality, because this deity belongs to the Vaishnavite Hindu tradition.

Once the Sattva Company had provided the first 2 acres, S. Ramani Anna launched two trusts: the Panchamukha Sri Jayamaruthi Seva Trust, which is private and "entrusted with all capital works for the temple", and the Panchamukha Sri Jayamaruthi Charitable Trust, which "takes care of all the charitable activities associated with this kșetram ${ }^{20}$. Thus, the first private trust is not exempt from taxes, whereas the second one, which is charitable, is. Today, 12 trustees, most of whom hold very good positions and high-powered jobs ${ }^{21}$ mainly in Chennai, manage the two trusts.

The purposes of the donors and trustees seem to correspond to the notion of evergetism which consisted, for the Greco-Roman notables (Veyne 1976), in main- taining their status by sponsoring the welfare of the community through the building of monuments, organisation of festivals, gifts of food, and so on - a phenomenon which has already been observed in India as well. For instance, Singer (1972) noted the religious observances of industrial leaders in Chennai, especially their involve- ment in pilgrimages, the patronage of religious festivals, financial support of monasteries and temple endowments. Furthermore, Clémentin-Ojha and Lachaier (2008) observed that the social status of Hindu merchants and industrialists depends not only on their wealth but also on their generosity, especially in terms of religious activities. Furthermore, the participation in temple trusteeship establishes and main- tains reciprocal trust relationships among members, facilitating the exchange of professional information or the pooling of resources. Finally, we should bear in mind /p.328/ that the position of temple trustee has been highly honorific for centuries in Tamil society. The growing involvement of the former Chief Minister Jayalalithaa and other MLAs as well as local politicians in temple building and renovations since the 1990s attests to the symbolic capital inherent to the participation in temple matters. Thus the involvement of "big men"22 in religious activities should not be underestimated for an understanding of why temples are profusely endowed and able to trigger the emer- gence and development of localities in south India.

\subsection{Real Estate Development}

What is particularly striking in this case is that the Panchavadi temple provoked a real estate

\footnotetext{
${ }^{20}$ www.panchavatee.org.

${ }^{21}$ The 12 trustees are: Prop. of Tours and Travels (Chennai); Vice President of Sattva Group of Companies (Chennai); Chairman of G.E.T. Power Projects (Chennai); Managing Director of Nagappa Motors (Chennai); Management Consultant and Former Dean of SCS Kothari Academy for Women (Chennai); Senior Advocate at Madras High Court (Chennai); Former Standard Chartered Bank (Bahrain) Manager and President of Guruvayurappan Asthika Samajam (Chennai); Managing Director of Dhinamalar (Puducherry); Chairman of Aravind Traders (Karur); Former Judge in Madras High Court (Chennai); Former General Manager of BSNL (Chennai); Former Engineering Director of Metro Water Board (Chennai).

${ }^{22}$ See also De Neve (2000).
} 
development in the former agricultural lands surrounding the site. Indeed, this new big temple has given a religious importance, and thus a higher value, to the locality. As a result, many agricultural lands have been converted into plots destined for residential use. A first company led the main real estate program in 2011. In July 2012, 57 plots ranging from 20 feet by 60 feet (sold at 3 lakhs each) to 20 feet by 65 feet (3.6 lakhs) were available in close proximity to the temple and several residential houses had already been built. This new residential area has been named "Jaya Ram Nagar" in reference to the Vaishnavite deities worshipped in the new big temple, which illustrates its symbolic importance.

Surprisingly, the real estate company has neither connections with the temple nor the trustees, excepting the fact that it set up an office right in front of the temple. The company merely recognised the development potential of this area as it is close to the highway and to Puducherry and this was enhanced by the erection of the massive new temple. The fact that the temple serves as the main argument in the advertisements for these plots is also very significant to the added value provided by the presence of the temple.

Another company in a neighbouring locality (Sedarapet) has carried out a second real estate program of approximately the same size. It confirms the interest in real estate development around the temple, and therefore the connection between the temple and the development of the locality, which contributes to the transformation of the local geography.

Nevertheless, the establishment of the Sattva Company in Panchavadi did not have a real impact on employment in the locality because the place is used essentially for storage and very few local people work for the company there ${ }^{23}$. Most of the population works in agriculture and the small industries of Sedarapet. However, in 2012, there were already a dozen shops near the temple as well as numerous women who sold ritual offerings (tulasi) for the devotees.

\section{$/ p .329 /$}

\subsection{Reformulation of the Local Socio-Religious Geography}

The Paňcamukha Āñjanēya temple was founded in a very surprising place. Indeed, this great orthoprax temple, its priests being Brahmins, is located in a Scheduled Caste colony (cēri), that is a hamlet of Dalits (Paraiyars) who have no relation with the temple founders. Actually, the Panchavadi hamlet is the $c \bar{e} r i$ of the Rawthankuppam panchayat village, whose main settlement $(\bar{u} r)$ is located a few hundred yards towards the north east of the temple. This location is thus completely contrary to the regular model of organisation of the settlements of castes, gods and temples in Tamil villages, because temples with Brahmin officiants are never located in cēris because of the "ideology of the pure and the impure" (Dumont 1966) which defines cēris as "impure" spaces, where great Puranic gods never settle and Brahmins never officiate.

This disconnection of the new Hanumān temple from the local socio-ritual geography is also apparent in the fact that the only other temple in Panchavadi (a very small shrine dedicated to the local goddess Māriyamman) is worshipped only by the local Paraiyar community. Similarly, the main temple of the whole pan- chayat village, which is located in the $\bar{u} r$ of Rawthankuppam and dedicated to another local goddess, is also visited only by the local population. Furthermore, there is no ritual interaction between the new temple and the older local temples during any festivals or processions, and this is particularly revealing of the dis- connection between the new Hanumān temple and local society, at least for the moment.

\footnotetext{
${ }^{23}$ In 2012, of the four guards, the cleaner, the inspector, the superintendent and the nine super- visors employed there, only one person lived in Panchavadi.
} 
In addition, Philip Lutgendorf, who studied the flourishing devotion to Hanumān worship in the 1990s, associates the increasing popularity of the monkey god with "India's growing middle class" (1997: 325). Indeed, to date, the Panchavadi temple mainly attracts devotees belonging to the urban middle class coming from nearby towns and cities. The Paraiyars are permitted to enter the Hanumān sanctuary but most local people interviewed in the vicinity prefer worshipping in the older temples of the area, which they have known for a longer time, instead of at the private Hanumān temple, where, according to some of them, "the donations go to a few rich people". The temple is thus far better connected to external social networks than it is anchored in local society. As in the following case, its founding must then be regarded as a strategy for it to be placed on the map of the increasing religious cum spiritual tourism in India, related to the increasingly wealthy middle class.

To sum up, as the real estate development programs suggest, this new private temple has truly provoked the development of the locality. However, this new landmark also reformulates the local social and ritual geography, which no longer corresponds to the usual configuration of Tamil rural localities.

$/ p .330 /$

\subsection{A New Temple Trust to Buy Lands and Create Centrality}

The last case study is Moratandi. It is another small settlement (850 inhabitants in 2011), situated a few kilometres from Panchavadi. This example shows not only that temple trusts enable the stimulation of local economic activity, but also how they are instrumental in purchasing land and raising land values.

The Śri Lalithambigai Vēda Śivāgama Trust was formed in 2002 by Chidambaram Gurrukkal, a Brahmin astrologer who wished to build a temple dedicated to the nine planets (navagrahā, tam. navakkirakam) and especially to the god Śani (Saturn), which is in itself uncommon. Indeed, although most Tamil Shaivite temples contain a small shrine devoted to the nine planets (including Śani) in their sanctuary, temples specifically dedicated to these deities are very rare in Tamil Nadu, whereas astrology is very important in social life and has been growing increasingly popular for several decades. Hence, a great Śani-Navagrahā temple should be particularly attractive.

As a trained astrologer having worked in a small goddess shrine in Puducherry for many years, Chidambaram Gurrukkal decided in the early 2000s to found a temple trust to create a large shrine to Śani and the nine planets. The temple trustees he designated were his two sons (also priests and astrologists) and their wives.

For this purpose, Chidambaram Gurrukkal bought 2.5 acres of land in the locality of Moratandi, where plots were available, located a few hundred yards from the first tollgate on the highway leading to Chennai. The area was previously occupied by fields of casuarina trees until a real estate company converted 60 acres of this land into residential plots. The ritual consecration (maha kumpapișēkam) of the Śri Viśvarūpa Mahā Śanīśvara Bhagavān temple took place in 2006.

Just as for the Panchavadi Hanumān temple, the trustees claim that this temple is the "world's tallest 27-feet pañcaloka statue of Śani", as everyone can read on the donation receipts. The temple also contains a huge (at least 12 feet high) golden statue of Vināyaka, and each of the Navagrahā statues are more than 7 feet high instead of the usual height of 1-2 feet in regular temples. Furthermore, the trustees have named the sanctuary the "Śri Navagrahā Parihāra Kṣētram", asserting that this astrological "sanctuary" (kșêtram) is supposed to "heal" (parihāra) people's problems. All 
this is particularly revealing of the founder's ambition to attract a maximum of people to this new religious site. Even the names of the gods in the temple are written in Hindi (beside Tamil and English), something particularly unusual in Tamil Nadu, a state well known for its aversion to Hindi.

Six years after the temple was consecrated the project seems to be a real success, surfing on the increasing interest for astrology in India, the scarcity of Śani temples and the accessibility of the place. Indeed, this new Śani temple is located very close to Puducherry, which ensures a reservoir of devotees. Moreover, people driving along the highway are forced to stop when they arrive at the tollgate, and this can contribute to their urge to visit the temple. Of course, the choice of this very location is in no way a coincidence.

/p.331/ As a result, more and more devotees visit the temple and make donations to the trust, which has been able to buy 7 more plots in Moratandi and 3 acres in another village (near Auroville) thanks to this income. The trust built a school for priests on one of the Moratandi plots, but the others were still vacant in 2013. Nevertheless, they represent a good investment for the trust, which can sell the plots at a much better price after the presence of the temple raised the land value by approximately $50 \%$ within 10 years, according to local informants who took part in the real estate development of the site. Many residents denounce the speculative strategy of the founder who buys lands through his temple trust (but who has not sold any plots yet in 2013). What is certain is that all the landowners of Moratandi have benefitted from the installation of the temple through the increase in the land value.

Furthermore, the presence of the temple probably generates more profitable revenues than the previous use of the place for casuarina trees. For instance, during the 2011 edition of the main festival dedicated to Śani (Śani peyarcci), a local informant earned 18,000 INR with the three stands selling ritual offerings she installed for the occasion. In Panchavadi, there are already a dozen shops dedicated to the devotees of the temple, and very many more in Melmaruvathur and elsewhere.

Hence, the Moratandi case illustrates another major aspect of the economic and development potentialities of temple trusts: temple legislation enables investors to buy lands for and through temple trusts, but also to increase the land value thanks to the presence of a temple. Once again, this temple created an attractive place and participates in the economic emergence of the locality. Nevertheless, the presence of a highway tollgate and a prior real estate program in the temple vicinity, as well as the proximity of urban settlements, are also noteworthy in this process of local development.

\section{Conclusion}

Although Hindu temples are unanimously considered by historians as important actors in the expansion of urbanism and irrigation in medieval south India, their role in the development of localities has been neglected by recent urban studies. Yet temples must be seen as real actors of local development in contemporary India as well, especially because temple deities are regarded as having a juristic personality as they are still endowed with economic resources and landed properties managed by religious trusts.

South Indian temples partake in the development of their localities in many ways, as has been the case for centuries. They provide their settlements with specific symbolic identities, they attract visitors and investors from outside, they take part in the shaping of urban morphologies, they influence land usage through spatial restrictions and they are given lands on which economic 
activities are often implanted. Furthermore, although the geographical situation always plays a significant role in local development, among other things, the case studies show that $/ \mathbf{p . 3 3 1} /$ contemporary temples can generate growth and development in small settlements. This is the case in Melmaruvathur, Panchavadi and Moratandi, where the emer- gence of economic activities (shops, real estate programs) and development amenities (schools, colleges, hospitals) has been triggered by the creation of local temples. In such localities, the consecration of non-market places (temples) instates the possibility of a market around them. This exemplifies the importance of the "spatial prohibition of ownership" associated with sacred places in the emergence and structuration of human settlements, as proposed by structural geography. Indeed, the lands on which Hindu temples are founded belong to their deity only, but temples are able to motivate the rise of their localities and to structure their immediate environment.

Finally, the role of temples and temple trusts in the local development strategies implemented by investors deserves to be studied. Indeed, the Panchavadi case illustrates the capacity of a temple to stimulate real estate development in its vicinity, and the Moratandi case shows how a temple founder succeeded in developing an attractive religious site on the lands exempted from taxes he bought through his temple trust. Such strategies can also be observed in much bigger south Indian localities, such as Bangalore, where a charitable trust belonging to the International Society for Krishna Consciousness (ISKCON) is currently developing a township which include hundreds of residential units as well as a commercial centre and a business centre, close to a large religious and touristic complex ded- icated to Krishna. The purpose of this complex is to generate income to promote the aims of the trust ${ }^{24}$. It shows that, although urban studies neglect the influence of temples on local development, probably because they are non-market places, many investors are perfectly aware of the possibilities that temples and religious trusts offer in terms of business and development in areas in south India. More broadly, these examples illustrate the interest of the "economics of religion" in the study of the connections between Hindu temples and local development.

Acknowledgments I thank E. Denis, M.-H. Zérah, A. Baviskar and G. Tarabout for their comments on the first draft of this chapter and Venkata Subrahmanyam for his company in the field. I also thank the SUBURBIN programme, the French Institute of Pondicherry, the Centre for Social Sciences and Humanities of New Delhi and the French National Research Agency (ANR) for the funding and the resources provided to carry out this research.

\section{References}

Annoussamy. (2001). Le droit indien en marche. Paris: Société de législation comparée. Appadurai, A. (2008 [1981]). Worship and conflict under colonial rule: A south Indian case. Cambridge: Cambridge University Press.

Appadurai, A., \& Breckenridge, C. (1976). The south Indian temple: Authority, honour and redistribution. Contributions to Indian Sociology, 10, 187-211.

Berti, D., Tarabout, Gi., \& Voix, R. (Eds.). (2016). Filing religion. State, hinduism and courts of law. Delhi: Oxford University Press.

Business Standard. (2010). Temple trusts chant new investment mantras. Namrata Acharya, February 06, 2010.

Clémentin-Ojha, C. (2010). L'insertion des convictions religieuses dans les droits positifs contemporains: le cas de l'Union indienne, paper presented at the conference on 'Convictions

\footnotetext{
24 “Temple trusts chant new investment mantras", Namrata Acharya, Business Standard, Feb 06, 2010.
} 
philosophiques et religieuses et droits positifs' (pp. 324-366), Centre international de la Common Law, Moncton, August 24-27, 2008.

Clémentin-Ojha, C., \& Lachaier, P. (Eds.). (2008). Divines Richesses. Religion et économie en monde marchand indien. Paris: Ecole Française d'Extrême Orient.

Das, T. K., \& Ray, I. D. (2008). Monopolistic competitive market in religion: A case study of hindu temples. Applied Economic Letters, 15(1), 69-72.

Dayalan, D. (1992). Early temples of Tamilnadu: Their role in socio-economic life (c. A. D. 550925). Delhi: Harman Publishing House.

De Neve, G. (2000). Patronage and 'community': The role of a tamil 'village' festival in the integration of a town. The Journal of the Royal Anthropological Institute, 6(3), 501-519.

Denis, E., Mukhopadhyay, P., \& Marie-Hélène, Z. (2012). Subaltern urbanisation in India. Economic \& Political Weekly, xlvii(30), 52-62.

Desmarais, G. (2001). Pour une géographie humaine structurale/Elements of structural geography. Annales de Géographie, 110(617), 3-21.

Dumont, L. (1966). Homo hierarchicus. Essai sur le système des castes et ses implications. Paris: Gallimard.

Fuller, C. J. (2003). The renewal of the priesthood. Modernity and traditionalism in a south Indian temple. New Delhi: Oxford University Press.

Gaucher, J. (2007). De la maison à la ville en pays tamoul ou la diagonale interdite. Enquête sur les formes urbaines de la ville-temple sud-indienne. Paris: Editions de l'Ecole Française d'Extrême Orient.

Geddes, P. (1976 [1919]). The temple city. In: J. S. Ferreira \& S. S. Jha (Eds.), The outlook tower. Essay on urbanization in memory of Patrick Geddes (pp. 461-475). Bombay: Popular Prakashan.

Guilmoto, C., Reiniche, M.-L., \& Pichard, P. (1990). Tiruvanamalai: un lieu saint sivaïte du sud de l'Inde. Pondichéry: Editions de l'Ecole Française d'Extrême-Orient, volume 5 «la ville».

Heitzman, J. (1987). Temple urbanism in medieval South India. The Journal of Asian Studies, 46 (4), 791-826.

Iannacone, L. (1998). Introduction to the economics of religion. Journal of Economic Literature, XXXVI, 1465-1496.

Karashima, N. (1984). South Indian history and society. Studies from inscriptions, A.D. 850-1800. Delhi: Oxford University Press.

Lutgendorf, P. (1994). My Hanuman is bigger than yours. History of Religions, 33(3), 211-245. Lutgendorf, P. (1997). Monkey in the Middle. The status of Hanuman in popular hinduism. Religion, 27, 311-332.

Mukherjea, B. K. (2003 [1952]). The hindu law of religious and charitable trust. Calcutta: Eastern Law House Ltd.

Narayanan, Y. (2015). Religion, heritage and the sustainable city. Hinduism and urbanisation in Jaipur. Routlegde: London.

Obadia, L. (2013). La marchandisation de Dieu. CNRS Editions: L'économie religieuse. Paris.

Presler, F. A. (1983). The structure and consequences of temple policy in Tamil Nadu, 1967-81.

Pacific Affairs, 56(2), 232-246.

Presler, F. A. (1987). Religion under bureaucracy. Policy and administration for hindu temples in south India. Cambridge: Cambridge University Press.

Punzo-Waghorne, J. (2004). Diaspora of the gods. Modern hindu temples in an urban middle-class world. New York: Oxford University Press.

Reiniche, M.-L. (1985). Le Temple dans la localité: Quatre exemples au Tamilnad. In: J. C. Galey (Ed.), L'Espace du temple 1 (pp. 75-121). Paris: Editions de l'EHESS, Coll. Purusartha, $\mathrm{N}^{\circ} 8$. Reiniche, M.-L. (1989). Tiruvanamalai: un lieu saint sivaïte du sud de l'Inde. Pondichéry: Editions de l'Ecole Française d'Extrême-Orient, Volume 4 «La configuration sociologique du temple

hindou».

Sastri, N. (1937). The Cholas, Part II. Madras: University of Madras.

Shinde, K. A., \& Pinkney, A. M. (2013). Shirdi in transition: Guru devotion, urbanisation and regional pluralism in India. South Asia: Journal of South Asian Studies, 36(4), 554-570. 
Singer, M. (1972). Industrial leadership, the hindu ethic, and the spirit of socialism. In M. Singer (Ed.), When a great tradition modernizes. An anthropological approach to Indian civilization (pp. 272-382). Delhi: Vikas Publishing House.

Stein, B. (1960). The economic function of a medieval south Indian temple. Journal of Asian Studies, XIX, 163-176.

Stein, B. (1961). The state, the temple and agricultural development: A study in Medieval South India. Economic Weekly Annual, XIII(4-6), 179-187.

Tamil Development, Religious Endowments and Information Department, Hindu Religious and Charitable Endowments Department, 2014, Demand N²7, Policy note 2014-2015.

Tarabout, G. (2006 [1996]). Les transformations de l'hindouisme. In C. Jaffrelot (Ed.), L'Inde contemporaine. De 1950 à nos jours (pp. 568-579). Paris: Fayard, CERI.

The Hindu. (2003). Hanuman's special avatar as Annihilator. Friday, March 07.

Varadachari, V. K. (1968). The law of hindu religious and charitable endowments. Lucknow: Eastern book Co.

Veyne, P. (1976). Le Pain et le cirque. Sociologie historique d'un pluralisme politique. Paris: Editions du Seuil. 